\title{
Pleasure and historical memory in Spanish Gothic film
}

\section{Ann Davies, University of Stirling}

Abstract

This essay argues that scholars of Spanish culture are too ready to assume a reading of Gothic texts in terms of historical memory, or the rectification of injustices that occurred during the Franco era. It suggests that there has been a neglect of the question of the pleasures of reading or viewing the Gothic, even though these pleasures may well undermine the desire to do retrospective justice to the victims of Franco. Using as a case study the film Insensibles Uuan Carlos Medina 2012) this essay proposes some examples of pleasures that serve to disrupt the recuperation of historical memory, and calls for better awareness of the pleasures of genre in analysing relevant texts.

Este ensayo sostiene que los que investigan la cultura española adoptan demasiado fácilmente una lectura de textos góticos en términos de la memoria histórica, o sea la rectificación de injusticias que ocurrieron durante la época franquista. Sugiere que se ha olvidado la cuestión de los placeres de leer o ver lo gótico, aunque estos placeres bien que puedan debilitar los esfuerzos de conseguir una justicia retroactiva para las víctimas de Franco. Utilizando como ejemplo el film Insensibles (Juan Carlos Medina 2012) el ensayo propone unos instantes de placeres que sirven para estorbar la recuperación de la memoria histórica, y exige una percepción más clara de los placeres de género en cuanto al análisis de textos relevantes. 
Analysis of democratic-era Spanish texts in terms of twentieth-century specifically Francoist - Spanish history has become something of a cottage industry in Spanish studies. The number of articles has become too numerous to mention in the space I have here, but there are also a number of book-length studies on textual and cinematic representation of the Spanish Civil War (such as Archibald 2012; Gómez López-Quiñones 2006; Maroto Camino 2011; Ribeiro de Menezes 2014; Resina and Winter 2005; Winter 2006). This is a valuable body of work for the discipline and in many respects an impressive amount of research into what is often called 'historical memory'. Jo Labanyi, in a penetrating article on the politics of memory (that itself formed part of a special journal issue dedicated to the topic) argues for historical memory thus: 'today's demands to remember the Francoist repression represent an attempt to "recover" (reactivate) the demands for transitional justice that were sidelined at the time' (Labanyi 2008, 122). The need for such retrospective justice is one of which many working on recent and contemporary Spanish culture are well aware of and to which they pay good heed.

But the tunnel vision that is developing as regards historical readings is becoming dangerous. In her analysis of Pedro Almodóvar's La piel que habito (2011), Carla Marcantonio argues for an interpretation of the film in terms of the Spanish Civil War, suggesting that the film's violence 'becomes a means to acknowledge how deeply the violence of the Spanish Civil War and its aftermath is etched on Spain's social fabric' (Marcantonio 2015, 52). This is rather like saying that any act of screen violence must recall the specifically national 
violence carried out between 1936-9 (and beyond), while neglecting more contemporary and more obvious referents for this particular film, such as pressure on the body to be perfect and a sense long prevalent within horror film that science has too much malevolent control (see Aldana Reyes 2013). Commentators such as Marcantonio seem to take it as self-evident that films must be responding to the demands of historical memory. There are other explanations: Antonio Gómez López-Quiñones $(2006,14)$ points out that such films exist because they clearly respond to a commercial imperative, though saying this simply pushes the question of why? one step further back to ask why audiences want to see such films. Nonetheless Gómez López-Quiñones’s warning that 'resulta cuanto menos problemático que el consumo se convierta en la vía principal de concienciación histórica, política e ideológica' (15) is one that we do well to heed. Labanyi perceives a different danger:

I have become increasingly uncomfortable at the number of studies of representations of the civil war and its repressive aftermath that engage in textual analysis with little or no mention of the public debates inflecting the texts' production and reception (Labanyi 2008, 120).

This is a danger that must be exacerbated by the fact that, as Ángel Loureiro argues, the question of the past provokes strong feelings in Spaniards 'despite the fact that most of them have a very spotty and even outdated knowledge of it' (Loureiro 2008, 229). 
Another danger, however - and this is the danger I wish to address specifically in this essay - is the neglect of how a specific genre or mode might impact on the recuperation of Spanish history. Genre too can have its pitfalls. Writing on crime films, Juan A. Tarancón talks of the limitations of genre:

Genres always reduce the complexity of films to the lowest common denominator. There is nothing wrong with this provided that we regard genres as fluid, contingent conceptualizations that provide us with a different awareness of society for specific circumstances and not as a fixed, ready-made model to be 'discovered'once and again in individual films irrespective of the political, social, and cultural forces that make up the social context in which they are made and/or received (Tarancón, 2016, 46).

I am not sure that genres always reduce complexity; and it could equally be argued that genre frameworks allow new perspectives that serve to complicate our understanding of a text - at any rate, this is part of what I intend to argue in this paper. Once again, too, it is questionable how far a genre film must reflect the political, social and cultural forces that makes up this social context, or which particular elements are at play at any given time. Given that genre films are more prone than most to reducing themselves to formulae, producers, directors and scriptwriters have responded in part by deliberately playing with generic conventions, in this sense speaking to the history and context of the genre itself rather than or more than a wider historical context. Nonetheless Tarancón's point is well taken that genre can be reductive. The trouble is that as regards 
films about the recent Spanish past, or at least the critique of them, the positions have all too frequently been reversed. Tarancón goes on to argue that: 'Still, many scholars tend to arrange films into the mold of rigid, generic paradigms, selecting the evidence that confirms their preconceived ideas and obscuring the significance of everything that would produce a different outcome' (46). But this is often exactly what some Hispanists are doing in terms of historical memory, neglecting elements which might suggest an entirely different outcome for film analysis as regards genre, such as pleasure and fandom.

When it comes to analysing the specific genre or mode of the Gothic, the dangers become more pronounced precisely because the Gothic itself strongly inclines towards an emphasis on the past. As Gothicist David Punter remarks: 'Gothic is a mode - perhaps the mode - of unofficial history' (Punter 1996, 197). This would seem to fit very neatly the recuperation of the lost voices of Franco's defeated. Similarly Linnie Blake (2008) and Adam Lowenstein (2005) argue for a need for interpretations of horror in terms of national traumas. Horror and Gothic become, in Blake’s words, 'a fundamental questioning of those ideologically dominant models of individual, collective and national identity', models that serve to cover up the wounds of trauma (Blake 2008, 4). In our keenness to historicise we nonetheless run the very great risk or neglecting insights that come from other narrative frameworks than the historical one: the Gothic is not just a mode for telling unofficial histories. In these interpretations, genre or mode become simply excuses for history that take no account of the ways, the narrative frameworks, used to tell these stories. 
The analysis of Gothic films and ghost stories in terms of the recuperation of the lost voices of Spanish history began to be prominent with the introduction of hauntology - with all its Gothic overtones - to fit such history. This follows Labanyi's seminal and useful theorisation (2001) that draws on Derrida's hauntology which is the past as a spectral space, haunted by ghosts of history who have been ignored and demand to be heard: a space that Labanyi links to the film form in particular because of film's spectral quality. The emphasis on the spectral is a fundamental reason why hauntology continues to be used when discussing horror and Gothic texts: nonetheless, new strands of debate are beginning to emerge. Labanyi herself, for example, has theorised on the role of affect (2010), which Stuart Davis (2017) and Francis Lough (2017) apply to texts dealing with the Civil War. Davis and Lough's articles appear as part of a special issue of the Bulletin of Hispanic Studies devoted to 'memory work that looks backwards and forwards at the same time', work that is transformative of the present rather than simply looking back (Ribeiro de Menezes and King, 2017, 796). Yet when it comes to Gothic texts, hauntology still persists. In particular, in his seminal article on haunting and historical memory, José Colmeiro uses Labanyi's arguments as a basis for his own claim that the presence of ghosts in contemporary Spanish texts is far from coincidental (Colmeiro 2011, 30-32), and includes Gothic films in his analysis. The disruptive nature of pleasure in this process is, however, not considered; and in fact features little in any of the newer theorisations that are appearing.

Labanyi argues that are three ways of approaching the ghosts of the past: 
One can refuse to see them or shut them out, as the official discourses of the State have always done with the various manifestations of the popular imaginary, where for good reasons ghost stories are endemic. One can cling to them obsessively through the pathological process of introjection that Freud called melancholia, allowing the past to take over the present and convert it into a 'living death'. Or one can offer them habitation in order to acknowledge their presence, through the healing introjection process that is mourning, which, for Freud, differs from melancholia in that it allows one to lay the ghosts of the past to rest by, precisely, acknowledging them as past (Labanyi 2001).

Such an idea has been framed by Ángel Loureiro in terms of psychoanalysis rather than hauntology, but the effect is the same; spectres will continue to haunt us if we do not deal adequately with the past:

In its psychoanalytical variation, the psychological interpretation of historical memory usually states that some undesirable aspects of the past have been repressed and are therefore condemned to return as monsters or spectres haunting Spanish culture and society - a contemporary variation of the bromide that those countries that forget their history are condemned to repeat it. In a more extreme psychoanalytical version, the disagreeable past would reach the intensity of a trauma that, as such, will repeat itself infinitely until it is politically restored to its rightful place in the narrative of historical memory (Loureiro 2008, 228). 
Approaches to the question of historical memory therefore can and do vary: but the threefold approach identified by Labanyi persists, and I believe that Hispanic Studies is currently inclined towards the second of Labanyi's options. The insistence on interpretations of national trauma, to the exclusion of any other interpretation, has indeed reached obsessive levels. We could also possibly discern elements of the first approach, which would horrify many Hispanists who are (in my view, rightly) concerned with dismantling of the hegemonic discourse imposed by Francoism. I make this claim, however, in light of the fact that there is a neglect of how frameworks of popular discourse actually function, and of the fact that, as Labanyi observes, ghost stories are endemic in popular culture.

Labanyi argues that popular stories contain traces of national, community and family histories; and Hispanists have been assiduous in teasing out these traces. We have been less assiduous in recognizing that these popular stories serve other interests and refract other tensions (gender or class, for instance); that national history and a recuperation of a serviceable past is only one thing that such stories can be called upon to do. But we are also less assiduous in recognizing that the popular ghost story is designed precisely to evoke a thrill and fear, a pleasurable fear; and that this purpose can run counter to the notion of mourning. A brief example might help at this point. The ghost child Santi in Guillermo del Toro's El espinazo del diablo (2001) can be perceived as a symbol of those who were unjustly murdered during the Spanish Civil War. This interpretation arises because of his innocence and the fact that he is a child of a 
Republican: it also depends on whether we view his murderer Jacinto as a representative of the Nationalist right wing or not. What Santi seeks is a form of justice and restitution. If only the living child Carlos would stop running away from him in terror and listen to him! Yet when Carlos hides in a cupboard and Santi's malevolent eye suddenly appears in close-up at the keyhole, this is a startle moment that is hard to interpret in terms of mourning but easy to interpret in terms of genre or mode.

So insistent have we become on local and national meanings that we forget that such stories have their own history subject to influences beyond regional and national borders. Marina Warner's comment on the fairy tale applies to many popular narratives such as ghost stories:

The audience is not necessarily assembled in one place at one moment the circle loops out across the centuries, forming a community across barriers of language and nation as well as time. Think of it as a plant genus, like roses or fungi or grasses, which seed and root and flower here and there, changing species and colour and size and shape where they spring. [...] The stories' interest isn't exhausted by repetition, reformulation, or retelling, but their pleasure gains from the endless permutations performed on the nucleus of the tale, its DNA as it were (Warner 2014, 44-5).

The recuperation of twentieth-century Spanish history is one clear permutation of the Gothic story but, like the fairy tale, the Gothic tale also forms its own 
'community' across barriers of language, nation and time - and a community that is formed around the pleasures of such tales. Moreover, with all this effort to stress the national trauma purportedly lying behind these ghost stories, the message that these ghosts represent the lost voices of Francoist history does not seem to permeate beyond Hispanic Studies. As an example, we could consider Andrew Hock Soon Ng's work on women and Gothic domestic space (Ng 2015). At one point he quotes Brigitte Cherry, who argues that 'Horror films invariably reflect the social and political anxieties of the cultural moment' (quoted in $\mathrm{Ng}$ $2015,139)$, an argument that I think debateable. My own point here, however, is that Ng ignores the implications of what he quotes. Not much further on, in his discussion of The Others (Alejandro Amenábar 2001) and El orfanato (J. A. Bayona 2007), Ng makes no reference to any of the writings that discuss these films in terms of the specific Spanish context. The notion that Spanish horror films, including internationally known ones like El orfanato, must be seen in a Civil War context has not permeated beyond Hispanic Studies, and it is more than a little dispiriting that as Hispanists we seem simply to be talking to ourselves on this issue.

All these caveats should nuance our thinking when analysing texts of historical memory; and they come into play strongly when considering a Gothic film. To begin with, Gothic can be understood in commercial terms as a reference point for audiences, who may choose to watch such films for many reasons. The strong commonality of Gothic with the wider genre of horror is of particular import. An obvious commercial target for a horror film is an audience of horror fans, whose own demands may not coincide with that of those who enjoy watching films that 
explore the hidden side of history, though these demands may well overlap. Those who like to watch such films are not one homogenous mass, a fact indicated by the simple fact of there being many subgenres or modes of horror, of which the Gothic is arguably one. Matt Hills argues that 'horror texts can be used to perform and display types of agency, whether this is a knowledge of narrative worlds, of specific aesthetics, or of production and genre histories' (Hills 2005, 91). These types of agency need to be borne in mind when considering the potential recuperation of historical memory, as such agency may take as a focus cinematic elements which have little to do with historical subtexts and themes. Hills's comment, however, refers to fans looking for some sort of subcultural capital with which to distinguish themselves from non-fans, a move that I believe avoids the agency - and the pleasure - experienced by those who would not describe themselves as horror fans but who nonetheless enjoy a good ghost story. For here Labanyi's reminder of the endemic popularity of the ghost story comes into play: it can even form part of festivities (Halloween and Christmas being the obvious ones) where a wider community than that of the horror fan can experience a variety of pleasures. So, although I will continue to refer to Hills in the remainder of this essay, what interests me is the entire 'problem' of pleasure in all its forms, for both fan and non-fan. If there is pleasure, it seems to me, there is the possibility that recuperation of historical memory can be disrupted.

I refer to pleasure as a problem, for the pleasure that audiences take in horror films is initially a perplexing one: why would we voluntarily watch a film that by definition aims to invoke fear in us, and possibly revulsion as well? This is a 
question that scholars have aimed to answer through a variety of approaches, not all of them sympathetic (e.g Clover 1992, Hills 2005, Modleski 1986, Tudor 2002, Twitchell 1985). Tania Modleski's point that horror critique still needs some sort of alibi is worth noting:

It is indeed possible for the tutored critic versed in preparatory film culture to make a convincing case for the artistic merit of a film like The Texas Chainsaw Massacre, as long as art continues to be theorized in terms of negation, as long as we demand that it be uncompromisingly oppositional $(1986,162)$.

It is also worth considering Catherine Spooner's critique of academic approaches to the Gothic that insist on a value beyond pleasure, as a form of self-justification for study:

If Gothic is more than just the evocation of pleasurable fear - if it touches intimately on pressing social issues - then researching it becomes easier to justify, whether to funding bodies or critics of the humanities (Spooner $2017,15)$.

Malcolm Turvey critiques psychoanalytic accounts of horror film on similar grounds, in that enjoyment of a horror film can only be a cover for some other, subconscious purpose: 'Viewing horror films is not desired and enjoyed for its own sake in such theories, but as a means to something else that is desired and enjoyed' (Turvey 2004, 75). 
The Gothic is therefore only allowed to be pleasurable if it has some other purpose than simply offering the thrill of the Gothic. Viewing Gothic films in terms of Francoist history tends to enact a similar process: a reading in terms of such history offers the chance to highlight the injustices done under it. Yet this reading should not be inevitable; and it should certainly not exclude the possibility of pleasure as simply being less worthy. Allowing for pleasure opens these films up to new interpretations that must surely enrich our understanding of what these films are doing, while not necessarily obscuring the recuperation of national trauma. After all, as Turvey suggests, if we wish to recover an 'unconscious' desire - in this case, the addressing of trauma - we should still question why a Gothic or horror film is the vehicle that audiences would deliberately choose in order to address it.

Turvey does not himself suggest an alternative theory, and neither do I in this paper. Rather, I wish to pose possible examples of pleasure as ways in which historical readings are both facilitated and obstructed by Gothic horror, with the hope that in so doing I might open up for debate an important though neglected complexity in what is already a complex and far from smooth process. In order to examine this, I intend now to examine one film in detail, first to give a reading of it in terms of Francoist history and then to problematise that history by carrying out a reading with an emphasis on Gothic pleasure. The film I am taking for my purposes is Insensibles (Juan Carlos Medina, 2012). Insensibles has two narratives that soon turn out to be connected. The first, starting in the 1930s and running through to the 1960s, centres on a group of children who do not feel pain and 
who therefore cause harm to themselves and others. The harm is inadvertent but nonetheless they are considered undesirables. They are locked away in a remote Gothic castle called Canfranc, and become the focus of scientific study. Despite their remoteness they also experience the vicissitudes of twentieth-century history, as the castle is taken over first by Republican soldiers fighting the Spanish Civil War, then in turn by Franco's Nationalist troops, then by Nazi troops, and finally used by Franco's regime as a centre for the torture of dissidents. The central character in this plotline is Benigno (Ilias Stothart and Mot Stothart), a child who becomes violent, stabbing first a nun and then one of the doctors, hanging up the body of the latter till it becomes a skeleton. When the Nazis arrive, Benigno is renamed Berkano (Tómas Lemarquis), meaning 'rebirth' in Nazi mythology. As he grows to adulthood he becomes a torturer, first for the Nazis and then the Franco regime, never leaving the cell in which he was imprisoned as a child.

The other plotline features David (Alex Brendemühl), a surgeon who discovers that he urgently needs a bone marrow transplant if he is to live and bring up his newborn son (whose mother died in a car crash). David consults his parents in the hope of finding an appropriate bone marrow donor, but discovers they are not his biological kin: his father Adán (Félix Gómez as a young man, Juan Diego as an old man) took David as a baby from Canfranc prison where he (Adán) worked. David's investigation leads him to discover the secret of cell 17 where Benigno/Berkano was kept, a site of immense horror about which people refuse to speak directly. David finally penetrates Berkano's hiding place at Canfranc, where Berkano has preserved the body of the woman he loved, David's mother, a 
dissident prisoner taken to Canfranc in the 1960s for torture. Berkano does not speak, but he recognises David as his son through the gaze they exchange. David's dropped cigarette lighter has inadvertently set the place on fire: as they are engulfed in flames, Berkano embraces the dead woman while David watches. In voiceover David addresses his newborn son, saying that they will never know each other but that the son will have his own history and thus be free, and a man.

A historical reading of Insensibles is easy to carry out: it is barely a subtext as the references to history are so blatant. Every so often we are given a marker of the timeline with notifications of the relevant year $(1931,1935,1936$ and so on) in large figures that dominate the screen. Medina and his co-writer Luiso Berdejo have, of course, picked a timeline that deliberately draws on references to the Civil War and the Franco era. The start of the action in 1931 invokes and anticipates the Civil War to come, and is reinforced by the scene in which Benigno is taken away from his mother. Frequent shots of the Civil Guard, buttressing the authorities of the local mayor and priest, and restraining Benigno as he tries to run to his mother, underscore the malignity of the town's actions in shutting the children away by using a familiar motif of repressive authority. These historical referents help to explain how Benigno, a quiet child with courage and potential for good, as suggested in the scene where he helps heal a sick puppy, becomes a torturer for right-wing regimes. However, the contemporary plotline featuring David stresses the importance of finding out and recuperating the history that has been lost. Those who managed to survive and escape Canfranc - Adán and the dissident prisoner José (Pablo Colau and Genís Hernàndez) - argue that it is better to forget the past. David, however, 
insists on finding out because to him it is literally a matter of life and death: he needs his biological parents to provide a bone marrow match. At first glance, this seems a fairly obvious metaphor for Spain's need to recuperate its own history in order to remain in good health. Forgetting is death. But the younger generation in the shape of the newborn son is also emphasised: initially David is uninterested in his own survival now that he has lost his wife, but his friend Judith (Sílvia Bel) stresses that he needs now to live for his son, so that uncovering the secret history also becomes a gesture of support to the younger generations.

The film's ending does, however, undercut this to a great extent. Although the flashback scenes stress the brutality of Francoism for the audience, while the contemporary scenes underscore the need to remember the past and unearth its darker secrets, the final scenes suggest that instead the past should be left behind and a new history forged. David's voiceover to his son is crucial to this, implying that with his own immolation alongside his father and his mother, his unnamed son can make a new start, a new history, and only thus be free and, significantly, be a man. David seems to perceive the horrible history he has uncovered as emasculating, a historical weight with which he does not want to burden his son. It is apparently better to die in the fire alongside his father than survive to care for his son and tell him about the past. David thus accepts the message of the older generation, that it is better to forget. An earlier and equally brutal sequence emphasises this still further. The older Adán shoots himself in front of David, while David's adoptive mother lies dead in the bath (it is unclear whether she killed herself or whether Adán killed her). In this way what we 
might call a Francoist generation - it turns out that Adán's role at Canfranc was state torture alongside Berkano - also clears itself away from the scene so that a younger generation can start again with a clean slate. Countering the film's apparent emphasis on forgetting the past, however, the film's very existence and interwoven narratives is an implicit call to an audience not to forget: it invokes the Francoist past even as it disavows it. In this sense Insensibles fits with the texts that Gómez López-Quiñones identifies as having a central protagonist in the present, whose quest to discover the past is itself a narrative as much as that of the past he (and it is usually he) seeks to uncover (Gómez López-Quiñones 2006, ch. 1). Gómez López-Quiñones observes that: 'los protagonistas de estas obras terminan aceptando que "vivir hacia delante" demanda "pensar hacia atrás"'. However, the result here is not, as he goes on to suggest, a present that now has fullness and meaning to it (26). Instead, the present is now a tabula rasa. The past has been recuperated but only to discover that its erasure is necessary.

The film's title, Insensibles, also hints at the double and contradictory message of the narratives: it suggests a lack of awareness that can cause harm. The children's insensitivity to pain has its double in David's lack of awareness of his own sickness, that in turn mirrors his lack of awareness of his own past. In both cases, a lack of knowledge of pain can lead directly to death. Yet equally, the only way to move forward into the future is to cut out any cancerous growth, as with the tumorous kidney of the sick puppy in the flashback narrative. However, it is with the title that I would like to begin my alternative reading, to demonstrate how the Gothic mode can problematise historical readings. What is the explanation for the fact that a whole group of children in one area have fallen 
victim to this strange lack of sensation? A historical reading of this is also possible, of course: we could argue that this symbolises Spain's own insensitivity to the pain and divisions lying at the heart of its society, which will eventually infect the whole country and tear it apart. Nonetheless the local people come up with a different explanation, that the children are 'endemoniados' or, as the mayor puts it, a 'mal desconocido'. This explanation points to a possible lack of education prevalent in this society, and to the resort to superstition implied by the priest crossing himself and women fainting when Dr. Carcedo (Ramon Fontserè) reveals the injuries and insensitivity of the children. Again, a historical reading in terms of Spain's backwardness is possible. But equally, the local populace invoke a standard motif of the Gothic, the superstitious locals who have a suspicion of anything that they do not understand, including anything scientific. And the locals are usually right to be suspicious. The scene poses a contrast common in Gothic texts between those who have knowledge and education (such as the doctors in this scene) and those who do not: and there is pleasure to be had in the fact that the local knowledge of ordinary people can be seen to undercut the power of intellectuals. Insensibles thus quotes a tradition that undermines an association of the lost voices of the Francoist past with progressive values.

In reading both this scene and the film's title, the work of Rebecca E. Martin (1998) on repetition, pleasure, and the Gothic can help us in deciphering at least some of the pleasures that a film like Insensibles can provide. These encompass intertextuality, familiarity through repetition, and anticipation. One of the pleasures she refers to is the desire to keep reading (or keep viewing), so that 
consumption of the Gothic becomes a serial pleasure, but always a pleasure of anticipation that is never quite satisfied:

The Gothic provokes an 'unsuspected visual pleasure' in the reader with images that promise to show and promise to display the 'truth' of whatever the reader wants to see [...] If one image does not fulfill expectations, the next one may; repetition offers an endless possibility for the search for 'truth' in whatever form it is desired (Martin 1998, 82).

Clearly the title of Insensibles impels a desire to keep on viewing in order to discover the truth of the children's inability to feel pain (or to see whether David overcomes his own insensitivity to the needs of his newborn son). The quest to discover the truth can clearly overlap with the quest to recuperate memories of Francoist history but it should be noted that it is not actually synonymous with it: there are other truths that demand discovery beyond those of national history. However, Insensibles ironically denies any such truth, for in the end the children's insensitivity to pain is never explained or resolved. There is a gap in knowledge which, Martin argues, is typical of the Gothic: 'The textual gaps, the cuts, in hundreds of spectacular Gothic scenes, and the reader's attempt to fill those gaps by discovering what lurks just out of sight, is the story of the Gothic reader's reading' (80). Yet the Gothic never fills in those textual gaps, so the reader's - or the viewer's - search becomes perpetual. The constant need to know and the constant search for truth suggests that something else is going besides the recuperation of memory. However, the scene with the villagers also suggests other ways of understanding the mystery of the children's insensitivity, 
in terms of intertextual quotation and the use of familiar Gothic motifs to posit a complex opposition between local forms of knowledge and voices of authority. The very repetition of this motif can invoke the pleasure of recognition as well as anticipation as to how the scenario will play out in this particular instance. The pleasures of repetition and quotation are some way removed from the need to detect the traces of history, and suggest that at the very least, the use of Gothic motifs are never just about the haunting voices of the past but also about the pleasures of the text.

The search for historical memory and the lost voices of the past also have little to do with the opening sequence in which the whole concept of insensitivity to pain is posited. Insensibles begins with shots of a little girl walking hesitantly through the countryside. The sequence is shot in an explicitly Gothic style: menacing trees hem her in, dark shadows abound and the sounds of the woodland are spooky. As night falls, she comes across another little girl by a fire. The second girl's right forearm is bathed in flame - but it does not hurt her. Naively, girl number two assumes that if the fire cannot hurt her it cannot hurt her friend either, so she pours oil over the first girl and sets her alight. To begin with the exchange of flame looks beautiful, but the first girl catches fire and screams in pain. The initial impulse for this plotline has nothing to do with national trauma. However, the sequence also serves other purposes. One is the introduction of familiar Gothic elements that cue the audience into drawing on their own understanding and knowledge of Gothic films and other texts: the innocent, unprotected heroine; the sinister wood; the suggestion of pursuit. A second is the 
reversal in expectation that the sequence also cues the audience for: the fact that the real threat comes from another girl rather than the implied but unnamed threat deriving from the setting, the lighting and the soundtrack. These purposes both draw on the pleasures of quotation and anticipation that we considered in the village scene: pleasures heightened by the simultaneous thwarting and fulfilling of expectations in the threat to the little girl. There is a third purpose in the opening sequence: the guilty pleasure of spectacle. The spectacle derives from people catching fire, and the myriad meanings of fire offer multiple resonances to this scene. The spectacle of girl two bathed in flame offers beauty, wonder and surprise, for at this stage in the film we do not know how she is able to manage this. The guilt emerges with the painful screams of girl one, reminding us of the terror of fire previously held in abeyance with girl two - the basic knowledge that fire burns. This duality - the enjoyment of spectacle and guilt at its price - is common to genres beyond horror; but guilty pleasure does not sit well with the laying to rest of the ghosts of the past.

The opening sequence is also the first of intermittent scenes of body horror, which also offers pleasures which might be uncomfortable but which should not be ignored. Xavier Aldana Reyes talks of the Gothic as a genre or mode in which corporeal transgression is inherent: he argues that 'Morbid curiosity is part and parcel of body gothic, as it charts our interest in forms of violence and radical alterity that are attractive precisely because they often lie outside the remit of our direct experience' (Aldana Reyes 2014, 13). And he goes on to argue: 
Body gothic constitutes an invitation to the enjoyment of contextually dependent scenarios where the gaze may transgress the status quo by engaging with practices or images that go beyond received and contemporary notions of the respectable (14).

Included in this is the pleasure or exercise of self-reflexivity: Aldana Reyes is talking of 'a mode that seeks to involve readers or viewers viscerally, that actively endeavours to engage them in a self-aware game probing the limits of transgression' (166). The presence of body horror in a film dealing about the Francoist past gives rise to some uncomfortable contradictions. The bulk of body horror in Insensibles is historical and strongly associated with the Franco regime, although its graphic nature is usually implied rather than seen. Nonetheless, body horror is also a matter of pleasure, which complicates the recuperation of memories of violence to a very uncomfortable degree. The pleasures involved may include a vicarious sadism, a defiant demonstration of strength through a refusal to be shocked, or a fascination with the abject, all forms of the morbid interest that Aldana Reyes refers to. In fact, all are to some extent thwarted by the film's denial of the sight of horror. When David rips back the screens surrounding José, we expect an eyeline match to what he is looking at presumably what has become of José's body. But the counter shot never comes. When Berkano carries out torture on behalf of the oppressors we never see what it is he actually does, although when he waves the scissors around José's eyeball we get a fair idea. This visual frustration brings us back to Martin's point about the endless anticipation induced by the Gothic. However, this is not to say that the desire to see body horror, rather than imagine it, is not fulfilled. We do see 
horrific motifs: David is covered with blood in the hospital sequences, while Benigno's display of Dr. Holzmann's corpse is horrific (and indeed shocks the Nazi forces who discover it). The difficulty is that these shots have no specific link to Francoist history. David's blood is shed as the result of a car crash for which he himself is culpable (by falling asleep at the wheel), while Benigno's murder of and macabre display of Holzmann is because Holzmann killed Benigno's companion Inés (as an act of mercy) rather than because of any motivation on the part of the Nazis or Francoists. The horrors undergone in Canfranc may reflect the torture that actually occurred in Francoist prisons, but they also coincide with the morbid fascination of body Gothic that Aldana Reyes refers to and as such they undermine any desire for recuperation of the victims through the repeated desire to see more.

Insensibles also uses suspense and anticipation (the latter often thwarted) in ways typical of the Gothic but which sometimes go against the grain of recuperating history. Although the earlier flashback dates ground us in Civil War history, the date the film really encourages us to watch out for is in the 1960s, as we know this to be the timeframe in which David was born. It is therefore the 1960s sequences that hold the clue both to the mystery but also to the horror inherent in that mystery. The earlier dates serve as much to point towards the 1960s and to suggest a build-up to that time period, as to have significance in their own right. And possibly, by the time the film signals that we are in the 40 s and 50s, we may find that the history drags, keeping us away from the 1960s sequence when all will be revealed. Our satisfaction is invoked when we do eventually reach the 1960s and the final piece of the parentage puzzle (the 
identity of David's mother); and the satisfaction in the resolution of that puzzle diminishes the impact of any recuperation of Spanish history. The satisfaction is further heightened by the fact that our expectations were thwarted earlier. The friendship between Benigno and Inés (itself predicated to some extent on pain, as suggested by the classroom scene in which one removes the other's nails) points to Inés becoming David's mother in due course. But any such expectations are brought to an end by Holzmann's euthanasia of Inés. Our perplexity over this calls for an alternative resolution of the mystery, so our attention is drawn to that rather than to the historical events unfolding, which in the end get in the way of us discovering the solution to the mystery. As Hills observes:

By introducing a discourse of horror's pleasures as linked to 'ontological shock' $[. .$.$] we can consider the possibility that audiences do not always$ cognitively 'master' or intellectually 'resolve' a text. Instead, they can be 'mastered' by a text, that is, allowing themselves to be open to the knowing, game-playing manipulations of an aesthetic artefact (Hills 2005, 44)

Hills also quotes Philip Brophy (194) who argues that: 'Involved in a violent awareness of itself as a saturated genre...The contemporary Horror film knows that you've seen it before: it knows that you know what is about to happen; and it knows that you know it knows you know'. This game-playing, and awareness of game-playing, offer further pleasures in subcultural capital that also may not fit neatly with the idea that the recovery of lost voices enables a surmounting of trauma. The foreknowledge of how Gothic works contrasts with the perpetual 
postponement of satisfaction offered by repetition, and the resultant oscillation between these two positions provides a form of teasing suspense as to how the permutations will play out this time.

The examples of pleasure I have given do not in and of themselves render invalid those interpretations that aim to explore questions of historical memory; nor are they a systematic counter-theory. But they should give us pause. If we are to deal adequately with memory texts we must address genre and its pleasures, and not simply filter these out to give the 'pure' reading in terms of Civil War memory. For it turns out that there is no such thing as pure memory, but memory compromised by all the other narratives that circulate and interact with it. Perhaps to some extent the last word can again lie with Labanyi, who argues that:

Too many of the publications on (and cultural representations of) the victims of Francoist repression end up catering to a kind of feel-good factor in their unanimity about the ethical need for reparation. I have wanted to avoid creating such comfortable feelings in the readers of this [special journal issue on the politics of memory], since I do not find them politically helpful (Labanyi 2008, 124).

Labanyi's words coincide to a great extent with those of Modleski and Spooner, who I quoted earlier. What I would like to end with, however, is her emphasis on not feeling comfortable as the result of our exertions in unpicking and debating the historical memory of twentieth-century Spain. What I am offering here is not 
a new theory as to how we do this. Rather, I am warning of the dangers of ignoring narrative frameworks in our rush towards an ethical feel-good factor. A more complex understanding of Gothic and its uncomfortable pleasures ought to unsettle us at the very least and impel us to rethink how we use paradigms of historical memory. For Gothic is, and to a great extent always has been, about the repetitive, perpetual and perpetuating pleasures and teases of the ghosts of the past rather than an exercise in the ethics of history. We need to understand this fact better than we do.

\section{References}

Aldana Reyes, Xavier, 2013. 'Skin Deep? Surgical Horror and the Impossibility of Becoming Woman in Almodóvar's The Skin I live In', Bulletin of Hispanic Studies $90 / 7,819-834$.

Aldana Reyes, Xavier, 2014. Body Gothic: Corporeal Transgression in Contemporary Literature and Horror Film (Cardiff: University of Wales Press).

Blake, Linnie, 2008. The Wounds of Nations: Horror Cinema, Historical Trauma and National Identity (Manchester: Manchester University Press).

Clover, Carol J., 1992. Men, Women and Chainsaws: Gender in the Modern Horror Film (London: BFI Publishing) 
Colmeiro, José, 2011, 'A Nation of Ghosts?: Haunting, Historical Memory and Forgetting in Post-Franco Spain', 452 : Electronic Journal of Theory of Literature and Comparative Literature 4, 17-24 <http://www.452f.com/index.php/en/josecolmeiro.html> (last accessed 22 November 2017).

Davis, Stuart, 2017. "Reading Beyond CognitiveMeaning: Affective Strategies in Novels of the Spanish “Memory Boom"', Bulletin of Hispanic Studies 94/8, 801-15.

Gómez López-Quiñones, Antonio, 2006. La Guerra persistente: memoria, violencia y utopía: representaciones contemporáneas de la Guerra civil española (Madrid/Frankfurt: Iberamericana/Vervuert)

Hills, Matt, 2005. The Pleasures of Horror (London: Bloomsbury)

Labanyi, Jo, 2001. 'Coming to Terms with the Ghosts of the Past: History and Spectrality in Contemporary Spanish Culture', Arachne@Rutgers 1/1, <http://www.libraries.rutgers.edu/rul/projects/arachne/vol1_1labanyi.html> (last accessed 27 April 2017).

Labanyi, Jo, 2008. 'The Politics of Memory in Contemporary Spain', Journal of Spanish Cultural Studies 9/2, 119-25.

Labanyi, Jo, 2010. 'Doing Things: Emotion, Affect and Materiality', Journal of Spanish Cultural Studies 11, 223-33. 
Lough, Francis (2017), 'Ideology, Affect and the Body in Alberto Méndez's Los girasoles ciegos', Bulletin of Hispanic Studies 94/8, 847-61.

Loureiro, Ángel, 2008. 'Pathetic Arguments', Journal of Spanish Cultural Studies $9 / 2,225-37$

Lowenstein, Adam, 2005. Shocking Representation: Historical Trauma, National Cinema, and the Modern Horror Film (New York: Columbia University Press)

Marcantonio, Carla, 2015. 'Cinema, Transgenesis, and History in The Skin I Live In', Social Text 122, 33/1, 49-70.

Martin, Rebecca E., 1998. "'I Should Like to Spend My Whole Life in Reading It": Repetition and the Pleasure of the Gothic', Journal of Narrative Technique 28/1, 75-90.

Modleski, Tania, 1986. 'The Terror of Pleasure: the Contemporary Horror Film and Postmodern Theory', in Studies in Entertainment: Critical Approaches to Mass Culture ed. Tania Modleski (Bloomington: Indiana University Press), 155-66.

Ng, Andrew Hock Soon, 2015. Women and Domestic Space in Contemporary Gothic Narratives: the House as Subject ( New York: Palgrave Macmillan).

Punter, David, 1996. The Literature of Terror: A History of Gothic Fictions from 1765 to the Present Day vol. 2: the Modern Gothic (Harlow: Longman). 
Resina, Joan Ramon and Ulrich Winter, eds, 2005. Casa encantada: lugares de memoria en la España constitucional (1978-2004) (Frankfurt/Madrid:

Vervuert/Iberoamericana)

Ribeiro de Menezes, Alison, 2014. Embodying Memory in Contemporary Spain (New York: Palgrave Macmillan)

Ribeiro de Menezes, Alison and Stewart King, 2017. 'Introduction: the Future of Memory in Spain', Bulletin of Hispanic Studies 94/8, 793-9.

Spooner, Catherine, 2017. Post-millennial Gothic: Comedy, Romance and the Rise of Happy Gothic (London: Bloomsbury)

Tarancón, Juan A., 2016. 'Realism, Social Conflict, and the Rise of Crime Cinema in Spain', in Global Genres, Local Films: the Transnational Dimension of Spanish Cinema eds. Elena Oliete-Aldea, Beatrix Oria and Juan A. Tarancón (London: Bloomsbury), 43-60.

Tudor, Andrew, 2002. 'Why Horror?: the Peculiar Pleasures of a Popular Genre', in Horror: the Film Reader ed. Mark Jancovich (Hoboken: Taylor and Francis), 4755.

Turvey, Malcolm, 2004. 'Philosophical Problems Concerning the Concept of Pleasure in Psychoanalytical Theories of (the Horror) Film', in Horror Film and 
Psychoanalysis: Freud's Worst Nightmare ed. Steven Jay Schneider (Cambridge: Cambridge University Press), 68-83.

Twitchell, James, 1985. Dreadful Pleasures: an Anatomy of Modern Horror (New York: Oxford University Press)

Warner, Marina, 2014. Once Upon a Time: a Short History of Fairy Tale (Oxford: Oxford University Press).

Winter, Ulrich, ed., 2006. Lugares de memoria de la Guerra Civil y el franquismo: representaciones literarias y visuales (Madrid/Frankfurt:

Iberoamericana/Vervuert). 